$14^{\text {th }}$ Conf. Agric. Develop. Res., Fac. of Agric., Ain Shams Univ., March, 2019, Cairo, Egypt

Special Issue, 27(1), 605 - 613, 2019

Website: http://strategy-plan.asu.edu.eg/AUJASCI/

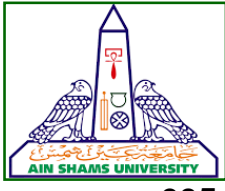

605

\title{
EFFECT OF SALINE WATER ON GROWTH, CHEMICAL COMPOSITION AND MICROBIOLOGICAL SAFETY EVALUATION OF RADISH ETIOLATED SPROUTS
}

\author{
Amira, M. Bondok ${ }^{1}$, Abd El-Gawad H.G. ${ }^{2}$, Zeinab, M. Abd El- Ghany ${ }^{1}$ and \\ Abdallah, M.M.F. ${ }^{2}$ \\ 1. Regional Center for food and Feed- Agriculture Research Center, Giza, Egypt. \\ 2. Horticultural Dept., Fac. of Agric., Ain Shams Univ., P.O. Box 68, Hadyek Shoubra \\ 11241, Cairo, Egypt
}

*Corresponding author: amirabondok@agr.asu.edu.eg

Received 24 February, 2019, $\quad$ Accepted 31 March, 2019

\section{ABSTRACT}

Egyptian radish sterilized seeds were sprouted for 3 days using tap and saline water $\mathrm{NaCl} 2000$ ppm to study sprout characters, chemical composition, protein fraction and safety aspects such as microbiological examinations and biogenic amines were investigated at 3 days old. The results indicated that sterilized seeds increased sprout growth compared with non-sterilized. Seeds sprouting increased in protein content, moister, ash and fibers while carbohydrate, lipid content and energy decrease in etiolated sprouts. Using saline water and seeds sterilization for sprouting increased albumin, globulin and glutenin fractionation but decreased prolamin compared with sprouts produced with tap water and without seed sterilization. Using sterilization by $2 \%$ calcium hypochlorite of seeds before sprouting led to decreasing in total bacterial count compared with non-sterile seeds sprouts, the same was in total coliform, total yeast and total fungi counts. The sprouts product which washed with saline water was contain total bacterial count less than which washed by tap water. All sprouts under investigation were free from feacal coliform and all examined pathogenic microorganism under investigation like Staph. aureus, B. cereus and Salmonella spp. Use sterilized seeds for sprouting caused big decrement on biogenic amines content of radish sprout. Radish sprout contain biogenic amines but it is lower than previous ranges, sprouts can be considered a safe food and germination of seeds either use tap or saline water.
Key words: sprouted seeds, growth, Chemical composition, Protein fraction, food safety, pathogens, saline water, Biogenic amines.

\section{INTRODUCTION}

It is well known that the consumption of plant based diet, mainly vegetables and whole grains, is recommended as one of the ways to lower the risk of human diseases (Cadenas and Packer, 2002). Sprouts is one valuable but still under-appreciated dietary supplement which may be considered to be a functional food and to meet consumer demands, as well a popular health food both in China and worldwide ( $\mathrm{Li}$ et al 2017). Eating the fresh sprouts is the best way of gaining all of the health benefits claimed for cruciferous sprouts because only minor losses in health-promoting components are likely to occur (Maetinez-Villauenga et al 2008). Radish (Raphanus sativus) is an edible vegetable, was used as medicinal foods for variety ailments in Egyptian folk-medicine long before the pyramids were built and was famous in ancient Egyptian, India; China and Rome as well (Abdallah, 2008).Salinization is increasing on a global scale, decreasing average yields for most major crop plants. So, salt stress is considered as the major limiting factors to seed germination and seedling growth in many places especially in arid and semiarid regions (Zivkovic et al 2007). Few studies have been carried out to investigate the effect of different concentration of $\mathrm{NaCl}$ on sprout germination and Microbiological quality of seed germination. To minimize microbial hazards in sprouts, the Food and Drug Administration (FDA, 1999) asked the National Advisory Committee on Microbiologi- 
cal Criteria for Foods (NACMCF,1999) to review the science behind sprout outbreaks and suggest recommendations to enhance sprout safety Ding et al. (2013). As an example, FDA cited 20000 ppm calcium hypochlorite for seed disinfection treatment. It is important to examine the effectiveness of the different seed disinfection treatments as one of the control strategies disinfection (FDA, 1999).

The aims of the present research were to evaluate Effect of $\mathrm{NaCl} 2000$ ppm (as one of the abiotic stresses) on Radish seed germination of 3 days old using tap and saline water.

Effect of using tap water and $\mathrm{NaCl}$ solution for 3 days on proximate analysis, of seeds sprouting.

Effect of sterilized and non sterilized radish seeds sprouting using tap water and $\mathrm{NaCl}$ solution for 3 days on the protein fraction.

microbiological quality of seeds germination using tap water and $\mathrm{Nacl}$ solution for 3 days with sanitized and non sanitized seeds.

Effect of sprouting using saline water and sterilized seeds on the content of biogenic amines of 3 days old.

\section{MATERIALS AND METHODS}

This study was carried out in Horticulture Department, Faculty of Agriculture, Ain Shams University and the Regional Center for Food and Feed (RCFF), Agriculture Research Center (ARC), Egypt in the period 2016-2018.

\section{1- Seed sprout production}

Radish (Raphanus sativus), Was obtained from the crops Research Institute Agriculture Research center. Calcium hypochlorite $2 \%$ and $\mathrm{NaCl}$ were obtained from El- Gomhoria chemical company, cairo, Egypt.

Radish, seeds was cleaned to remove broken, damaged and off-colour grains. Egyptian radish seed sprout was produced using glass jar method and collect it after three days from seed soaking, (for both germinated in tap water and 2000 ppm $\mathrm{NaCl}$ solution, washed and hulled before dried according to Abdallah (2008). Radish seed and seed sprouts Samples of harvest tap and saline water was oven dried at $60^{\circ} \mathrm{C}$ for $48 \mathrm{~h}$. and ground in laboratory wiley mill to pass through a 40 mesh sieve. The ground sample was stored at $5^{\circ} \mathrm{C}$ until chemical analysis while fresh sprouts were used for microbiological examination.

\section{2- Chemical examination of seeds and sprouts \\ a- Proximate analysis}

Proximate analysis moisture, fat, ash, protein and fiber content of seeds and sprouts are determined according to AOAC (2012) using subtracting to determine total carbohydrate. The energy value was calculated using the method $[(9 \times$ fat $)+(4 x$ carbohydrate $)+(4 \times$ protein $)]$ as prescribed by Chima and Jgyor (2007).

\section{b- Protein fractionation}

Protein fractionation of albumin, globulin, glutelin and prolamin were analyzed in etiolated radish sprout at 3 days old with and without seed sterilized in tap and saline water 2000 ppm Nacl according to Lookhart and Bean (1995).

\section{3- Effect of 2000 ppm Nacl concentration on radish seeds sprouts production}

Radish sprout was produced using glass jar method and collect it at 3 days from seed soaking for both germinated in tap water and in 2000 ppm $\mathrm{NaCl}$ solution and sprout were produced without seed sanitizers.

\section{4- Effect of seeds sanitizing by calcium hypo- chloride $2 \%$ on sprouts production}

Radish seeds was soaked in calcium hypchloride solution $2 \%$ for $20-30$ min as seed sanitizing treatment the seeds was drained and rinsed several times with tap water to remove sanitizer residual, then seeds soaking in both tap water and 2000 ppm $\mathrm{NaCl}$ solution for germination.

\section{5- Microbiological examinations}

Microbiological examinations were carried out in Regional Center for Food and Feed, Agriculture Research Center (ARC). Radish seeds sprout samples examined for its microbiological quality and safety in, non- sterilized, and sterilized radish seeds sprout, which washed with tap and saline water.

Appropriate dilutions prepared from each sample were used for inoculating different nutrient and 
selective media. The microbial detection applied were:

\section{5-1. Total bacterial counts}

Bacterial counts were estimated on glucose yeast extract nutrient agar medium (Difco, 1989) using pouring plate technique. Suitable plates were counted after incubation at $37^{\circ} \mathrm{C}$ for 48 hours.

\section{5-2. Coliform and faecal coliform counts}

Coliform and faecal coliform counts were estimated on MacConkey agar (Difco 1989) using pouring plate technique. Suitable plates were counted after 24 hours at $37^{\circ} \mathrm{C}$ and $44.5^{\circ} \mathrm{C}$ for total coliform and faecal coliform counts, respectively.

\section{5-3. Staphylococcus aureus}

The numbers of Staph. aureus was carried out according to Gouda (2002). The isolation of Staph aureus based on appears as black, convex, shiny colonies surrounded by a yellow zone on Vojel Johnson agar medium. The plates were incubated at $37^{\circ} \mathrm{C}$ for 48 hours.

\section{5-4. Bacillus cereus}

The numbers of $B$. cereus were estimated on egg-yolk polymyxin agar medium according to Kim and Goepfert (1971). On this medium, presumptive $B$. cereus appears as large pink colonies.

\section{6-5.Salmonella spp.}

Twenty-five $\mathrm{g}$ of each sample were added to $225 \mathrm{ml}$ of peptone water as pre-enrichment medium and incubated at $37^{\circ} \mathrm{C}$ for 24 hours. Twenty five $\mathrm{ml}$ from pre-enrichment culture were added to $225 \mathrm{ml}$ of tetrathionate broth (Difco, 1989) as enrichment medium with incubation at $37^{\circ} \mathrm{C}$ for 24 hours. After incubation, the culture was streaked on Difcobrilliant green agar plates and examined after 18-25 hours (Georgela and Boothroyd, 1965 and Khan and McCaskey, 1973).On this medium, presumptive Salmonella appears as pink colonies surrounded by bright red medium.

\section{5-6. Total yeast and total fungi count}

Twenty five gram of the sample were transferred to a sterile flask and mixed well with $225 \mathrm{ml}$ of sterile peptone water $(0.1 \%)$ solution. From which a serial dilutions were done, $1.0 \mathrm{ml}$ was transferred with sterile pipettes from each dilution to a duplicate petri dishes with Rose Bengal chloramphenicol agar. Spread on the surface using a bent glass rod. The plates were placed in well ventilated plastic bags and incubated in an upright position at $25^{\circ} \mathrm{C}$ for 5-7 days (NMKL, 1995).

\section{6- Biogenic amines determination}

Six biogenic amines included histamine, Tyramine, Cadaverine, Spermine, Putresine, Spermidine were extracted and determinates according to (Frias et al 2007).

\section{Statistical analysis}

Statistical analysis was employed for each measured trait by analysis of variance (ANOVA) using completely randomized design and the mean were differentiated by LSD 0.05 (Snedcor and Cochran, 1980).

\section{RESULTS AND DISCUSSION}

\section{1- Effect of seed sanitizer and non-sanitizers on sprout characters}

Data in Table (1) showed the effect of both seed sanitizers soaked in calcium hypo chloride 2\% for 20-30 min and non-sanitizers on sprouting using saline water $2000 \mathrm{ppm}$ and tap water solution on 3 days old etiolated radish sprouts characters, sprout length, fresh and dry weight and radical hypocotyl length.

Data revealed that all different seed sanitizers were increased the fresh and dry weight in radish compared with non-sanitizers seeds. These results are in agreement by Rajkowski and Thayer 2001. 
Table 1. Effect of $\mathrm{NaCl}$ concentration in sprouting solution on 3 days old etiolated radish sterilized and non-sterilized seeds characters ( average of three experiments).

\begin{tabular}{|c|c|c|c|c|c|c|}
\hline Sterilization (Ste) & $\begin{array}{c}\text { NaCl con- } \\
\text { centration }\end{array}$ & $\begin{array}{c}\text { Sprout radi- } \\
\text { cal length } \\
(\mathrm{cm})\end{array}$ & $\begin{array}{c}\text { Sprout } \\
\text { hypocotyl } \\
\text { length }(\mathrm{cm})\end{array}$ & $\begin{array}{c}\text { Sprout } \\
\text { length } \\
(\mathrm{cm})\end{array}$ & $\begin{array}{c}10 \text { sprout } \\
\text { fresh weight } \\
(\mathrm{mg})\end{array}$ & $\begin{array}{c}10 \text { sprout } \\
\text { dry weight } \\
(\mathrm{mg})\end{array}$ \\
\hline & & \multicolumn{5}{|c|}{ Radish sprout } \\
\hline Sterilized seeds & Tap water & $5.56 \mathrm{a}$ & $2.54 \mathrm{a}$ & $8.13 \mathrm{a}$ & $954.33 \mathrm{a}$ & $96.4 \mathrm{a}$ \\
$\mathrm{NaCl}, \mathrm{ppm}$ & $2000 \mathrm{ppm}$ & $5.26 \mathrm{a}$ & $2.36 \mathrm{ab}$ & $7.60 \mathrm{~b}$ & $946.33 \mathrm{~b}$ & $95.0 \mathrm{~b}$ \\
mean & & $5.41 \mathrm{~A}$ & $2.43 \mathrm{~A}$ & $7.865 \mathrm{~A}$ & $945.00 \mathrm{~A}$ & $95.70 \mathrm{~A}$ \\
$\mathrm{Non}$ - sterilized & Tap water & $5.26 \mathrm{a}$ & $2.23 \mathrm{ab}$ & $7.8 \mathrm{~b}$ & $946.33 \mathrm{c}$ & $95.50 \mathrm{ab}$ \\
seeds & & & & & & \\
$\mathrm{NaCl}, \mathrm{ppm}$ & $2000 \mathrm{ppm}$ & $4.66 \mathrm{~b}$ & $2.16 \mathrm{~b}$ & $6.83 \mathrm{c}$ & $935.0 \mathrm{~d}$ & $95.26 \mathrm{~b}$ \\
mean & & $5.01 \mathrm{~B}$ & $2.20 \mathrm{~B}$ & $7.21 \mathrm{~B}$ & $944.65 \mathrm{~B}$ & $95.38 \mathrm{~B}$ \\
$\mathrm{Average}$ & Tap water & $5.41 \mathrm{~A}$ & $2.36 \mathrm{~A}$ & $7.866 \mathrm{~A}$ & $950.33 \mathrm{~A}$ & $95.95 \mathrm{~A}$ \\
$\mathrm{NaCl}, \mathrm{ppm}$ & $2000 \mathrm{ppm}$ & $4.96 \mathrm{~B}$ & $2.26 \mathrm{~A}$ & $7.216 \mathrm{~B}$ & $939.33 \mathrm{~B}$ & $95.13 \mathrm{~B}$ \\
$\mathrm{LSD}(0.05)$ & $\mathrm{Ste}$ & 0.2607 & 0.2105 & 0.2549 & 2.1051 & 0.7149 \\
& $\mathrm{NaCl}$ & 0.2607 & 0.2105 & 0.2549 & 2.1051 & 0.7149 \\
& Stex NaCl & 0.3686 & 0.2977 & 0.3605 & 2.977 & 1.011 \\
\hline
\end{tabular}

Means of each column followed by the same letter are not significantly different at the $5 \%$ level $(p \leq 0.05)$

\section{2- Effect of sprouting on proximate composi- tion.}

The proximate composition of sprouts and dry seeds radish sprouts using tap and saline water are presented in Table (2). Data showed using tap and saline water increased moister and protein content as compared with dry radish etiolated sprouts, could be due to a decreased in dry matter through respiration of young sprouts, due to here were no nitrogen source added externally to the water and saline solution used for irrigation during sprouts. This protein percent increase was therefore not a likely true increase (Chavan and Kadam 1989, Abdallah 2008 and Dung et al 2010) the increment of moister content in sprouts in a dry weight basis as compared with dry seeds state. The original dry weight of the seeds decreased during sprouting process. The decrement in dry weight may be due to leaching of materials and oxidations of substances from the seeds during sprouting as reported by (Chavan and Kadam 1989). Carbohydrate values by difference recorded opposite results with protein and showed clear eased volute in sprouts compared with dry seeds speedily when using tap and saline water for sprouting. Moister, fiber and ash value increased in radish sprouts than dry seeds, while energy value decreased in radish sprouts using tap and saline water as compared with dry seeds. This observation may be due to decreased in lipid and carbohydrate content.
Table 2. Effect of sprouting on proximate analysis of radish etiolated sprouts using tap water and saline water 2000 ppm dry seeds (g/100g DW).

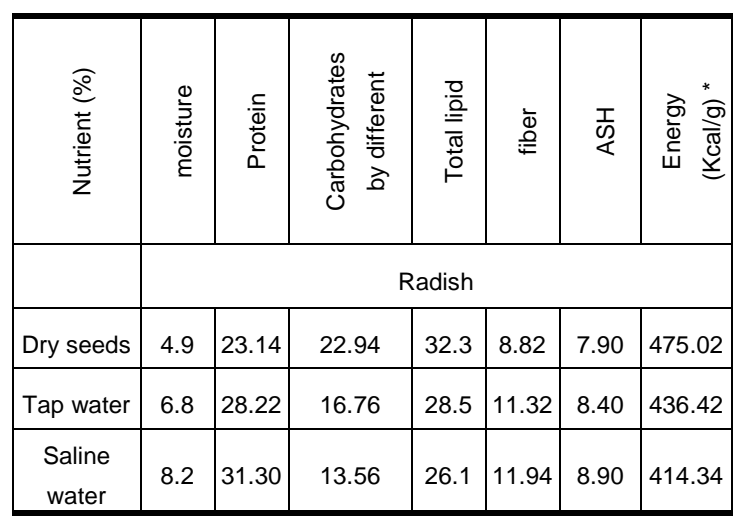

*Energy calculated according to Chima and Jgyor (2007) Kal/g.

1- Effect of sterilization and water saline $\mathbf{2 0 0 0}$ ppm on protein fractionation in radish sprouts:

Data in Table (3) revealed that radish seed sprout with saline water 2000 ppm Nacl recorded significant increase 56.18, 36.23 and 4.26 (mg/ $100 \mathrm{mg}$ ) sample in albumin, globulin and glutenin fractionation respectively. Whereas significant decrease occurred in prolamin $3.32(\mathrm{mg} / 100 \mathrm{mg}$ ) sample compared with sprouts produced with tap water with and without seed sterilized. Finally, albumin was the major radish sprout protein fraction 

evaluation of radish etiolated sprouts

extracted from Nacl 2000 ppm sprout followed by globulin. Therefore, the radish sprout could have excellent applications for future product development due to their nutritional properties. These results may be due to Exposure of salt stress altered the protein profiles and promoted the accumulation of salt-specific proteins was depended on genotypes, salt concentration and salt treatment duration. It was suggested that appearance of synthesized proteins in response to $\mathrm{NaCl}$ treatments might be related with the capability of metabolism to adjust or adapt to varying requirements in response to $\mathrm{NaCl}$ treatments and may be involved in osmotic adjustment (Win and Oo 2017).

Table 3. Effect of sterilized and non-sterilized radish seed sprouting using saline water ( $\mathrm{Nacl} 2000$ $\mathrm{ppm}$ ) on the protein fraction of 3 days etiolated radish sprouts characters $(\mathrm{mg} / 100 \mathrm{mg})$ samples.

\begin{tabular}{|c|c|c|c|c|c|}
\hline 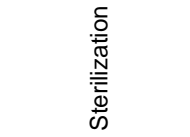 & 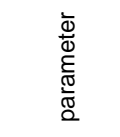 & 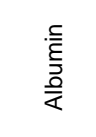 & $\begin{array}{l}\frac{.5}{\overline{3}} \\
\frac{0}{0} \\
\frac{0}{10}\end{array}$ & $\begin{array}{l}\frac{.5}{\overline{0}} \\
\frac{5}{0}\end{array}$ & 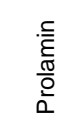 \\
\hline Sterilization & Tap water & $53.5 \mathrm{c}$ & $33.64 \mathrm{~d}$ & $3.8 \mathrm{~b}$ & $9.06 \mathrm{a}$ \\
\hline $\mathrm{Nacl}, \mathrm{ppm}$ & 2000 & $55.3 \mathrm{~b}$ & $35.66 \mathrm{~b}$ & $4.00 \mathrm{~b}$ & $5.04 \mathrm{c}$ \\
\hline Mean & & $54.40 \mathrm{~B}$ & $34.65 \mathrm{~B}$ & $3.90 \mathrm{~B}$ & $7.05 \mathrm{~A}$ \\
\hline Non sterilization & Tap water & $55.00 \mathrm{~b}$ & $34.70 \mathrm{c}$ & $3.90 \mathrm{~b}$ & $6.40 \mathrm{~b}$ \\
\hline $\mathrm{Nacl}, \mathrm{ppm}$ & 2000 & $57.06 \mathrm{a}$ & $36.80 \mathrm{a}$ & $4.53 \mathrm{a}$ & $1.61 \mathrm{~d}$ \\
\hline Mean & & $56.03 \mathrm{~A}$ & $35.75 \mathrm{~A}$ & $4.21 \mathrm{~A}$ & $4.00 \mathrm{~B}$ \\
\hline Average & Tap water & $54.25 \mathrm{~B}$ & $34.17 \mathrm{~B}$ & $3.85 \mathrm{~B}$ & $7.37 \mathrm{~A}$ \\
\hline $\mathrm{Nacl}, \mathrm{ppm}$ & 2000 & $56.18 \mathrm{~A}$ & $36.23 \mathrm{~A}$ & $4.26 \mathrm{~A}$ & $3.32 \mathrm{~B}$ \\
\hline \multirow[t]{3}{*}{ LSD 0.05} & Ste & 0.330 & 0.358 & 0.285 & 0.356 \\
\hline & $\mathrm{Nacl}$ & 0.330 & 0.358 & 0.285 & 0.356 \\
\hline & Ste $\times \mathrm{Nacl}$ & 0.467 & 0.507 & 0.403 & 0.504 \\
\hline
\end{tabular}

Means of each column followed by the same letter are not significantly different at the $5 \%$ level $(p \leq 0.05)$

Microbiological examination (CFU/g) of radish seeds sprout with tap and saline water 2000 ppm at home conditions

The data in Table (4) cleared that total bacterial counts in non sterile seeds sprouts was ranged from $9 \times 10^{2}$ to $12 \times 10^{3} \mathrm{CFU} / \mathrm{g}$ in seeds sprouts which washed with saline and tap water respectively, while in sterile seed sprouts the total bacterial count was $6 \times 10$ and $5 \times 10 \mathrm{CFU} / \mathrm{g}$ for sprouts washed with tap and saline water. Total coliform group was recorded as $5 \times 10 \mathrm{CFU} / \mathrm{g}$ only in non sterile seed sprouts washed with tap water. All sprouts under investigation were free from coliform group, Staph. aureas, Salmonella spp. and B. cereus was ranged from 10 to $70 \mathrm{CFU} / \mathrm{g}$ in non sterile seed sprouts washed with saline and tap water respectively. Total yeast and total fungi counts were counted as $7 \times 10^{2}, 3 \times 10^{2} \mathrm{CFU} / \mathrm{g}$ and $15 \times 10$, $11 \times 10 \mathrm{CFU} / \mathrm{g}$ in non sterile seed sprouts washed with tap and saline water respectively. Similar results for undetected Salmonella spp and faecal coliform were reported by Prokowich and Blank (2001) and Ibrahim (2010). On contrary Ibrahem (2010) detected Staphylococcus aureus in radish seeds sprouts and rocket sprouts. Data in Table 4 explain the microbiological quality of sterilized radish seeds sprout with calcium hypochlorite and washed with tap and saline water were free from any microbial groups expect total bacterial count.

Table 4. Microbiological examination $(\mathrm{CFU} / \mathrm{g})^{*}$ of non-sterile and sterile radish seeds sprout at home conditions.

\begin{tabular}{|c|c|c|c|c|}
\hline \multirow[t]{2}{*}{ Species } & \multicolumn{2}{|c|}{ Non-sterile sprout } & \multicolumn{2}{|c|}{ Sterile sprout } \\
\hline & $\begin{array}{c}\text { Tap wa- } \\
\text { ter }\end{array}$ & $\begin{array}{l}\text { Saline } \\
\text { water } \\
(2000 \\
\text { ppm })\end{array}$ & $\begin{array}{c}\text { Tap } \\
\text { water }\end{array}$ & $\begin{array}{l}\text { Saline } \\
\text { water } \\
(2000 \\
\text { ppm) }\end{array}$ \\
\hline $\begin{array}{c}\text { Total bacterial } \\
\text { count }\end{array}$ & $12 \times 10^{3}$ & $9 \times 10^{2}$ & $6 \times 10$ & $5 \times 10$ \\
\hline $\begin{array}{l}\text { Total coliform } \\
\text { count }\end{array}$ & $5 \times 10$ & ND & ND & ND \\
\hline $\begin{array}{c}\text { Faecal coliform } \\
\text { count }\end{array}$ & ND & ND & ND & ND \\
\hline $\begin{array}{c}\text { Staphylococcus } \\
\text { auraus }\end{array}$ & ND & ND & ND & ND \\
\hline Bacillus cereus & $7 \times 10$ & $1 \times 10$ & ND & ND \\
\hline Salmonella spp. & ND & ND & ND & ND \\
\hline Total yeast count & $7 \times 10^{2}$ & $15 \times 10$ & ND & ND \\
\hline Total fungi count & $3 \times 10^{2}$ & $11 \times 10$ & ND & ND \\
\hline
\end{tabular}

${ }^{*}$ Colony Forming unit, ND: not detected

Therefore, these results were in harmony with Ding et al 2013 reported that Microbial contamination of sprouts by Salmonella and Escherichia coli cause foodborne diseases, they reduce the risk of illness associated with contaminated sprouts with these microbes by using Food and Drug Administration recommendation using 20000 ppm calcium hypochlorite as treatment for seed treatment and this treatment has been considered the reference standard for seed disinfection treatment. Fur- 
thermore, our results showed that sprouts treated with saline water at concentration 2000 ppm was reduced the total microbial count of radish sprouts without using 20000 ppm calcium hypochlorite. As a result, we recommend treat sprouts with saline water at $2000 \mathrm{ppm}$ to disinfestation them from microbial contamination.

\section{Effect of sprouting using saline water and steri- lized seeds on the content of biogenic amines of 3 days old etiolated radish sprouts.}

The results of biogenic amine contents of radish sprouts and grains are given in Table (5). Six biogenic amines were investigated in the experiment spermine, putrescine, cadaverine, histamine, tyramine and spermidine were 11.59,14.62, 14.39, 15.47, 7.37 and $16.68 \mathrm{mg} / \mathrm{Kg}$ respectively non strilized of radish sprouts with tap water. However, all biogenic amines were detected in big amounts of radish sprouts with saline water. Sterilization of radish seeds decrease the amines content in radish sprout of tap and saline water Table (5). From the obtained results its clearly to say that all radish sprout samples were free from any biogenic amines except cadaverine and histamine were 0.11 and $0.10 \mathrm{mg} / \mathrm{Kg}$ respectively in radish sprouts with saline water. On the other hand, cadaverine was $0.11 \mathrm{mg} / \mathrm{Kg}$ in radish sprouts with tap water.

Radish dry seeds contain $4.28 \mathrm{mg}$ of spermine, $9.57 \mathrm{mg}$ of putrecine, $11.20 \mathrm{mg}$ of cadaverine, $10.93 \mathrm{mg}$ of histamine, $2.76 \mathrm{mg}$ of tyramine and $8.42 \mathrm{mg}$ of spermidine and most of these amines were slightly increased after sprouting seeds either use tap or saline water. These results were in parallel with Shalaby (2000) who showed that cadaverine and putrescine increased during the germination period in bean, lupine and chickpea seeds. Tryptamine can induce blood pressure increase, therefore causes hypertension, however there is no regulation on the maximum amount of tryptamine Shalaby (1996). However, Parente et al (2001) and Nout (1994) pointed out that the maximum and daily intake of histamine and tyramine should be in the range of $50-100 \mathrm{mg} / \mathrm{Kg}$ and 100 $800 \mathrm{mg} / \mathrm{Kg}$ respectively over $1080 \mathrm{mg} / \mathrm{Kg}$ tyramine becomes toxic.

Table 5. Effect of sprouting using saline water on the biogenic amines content $(\mathrm{mg} / \mathrm{kg} /)$ of 3 days old etiolated radish sprouts.

\begin{tabular}{|c|c|c|c|c|c|c|c|c|}
\hline \multicolumn{2}{|c|}{ Treatment } & Spermine & $\begin{array}{c}\text { Putres- } \\
\text { cine }\end{array}$ & $\begin{array}{c}\text { Cadav- } \\
\text { erine }\end{array}$ & $\begin{array}{c}\text { Hista- } \\
\text { mine }\end{array}$ & Tyramine & $\begin{array}{c}\text { Spermi- } \\
\text { dine }\end{array}$ & Total \\
\hline \multirow{2}{*}{ Sterilized } & TW & ND & ND & 0.11 & ND & ND & ND & 0.11 \\
& SW 2000 & ND & ND & 0.11 & 0.10 & ND & ND & 0.21 \\
\hline \multirow{2}{*}{ Mean } & & ND & ND & 0.11 & 0.10 & ND & ND & 0.16 \\
\hline \multirow{2}{*}{ Non sterilized } & TW & 11.59 & 14.62 & 14.39 & 15.47 & 7.37 & 16.68 & 80.12 \\
& SW 2000 & 13.42 & 17.23 & 15.65 & 16.38 & 8.46 & 17.18 & 88.32 \\
\hline \multirow{2}{*}{ Mean } & & 12.51 & 15.93 & 15.02 & 15.93 & 7.92 & 16.93 & 84.22 \\
\hline \multirow{2}{*}{ Average } & TW sprout & 5.79 & 7.31 & 7.25 & 7.74 & 3.69 & 8.34 & 40.13 \\
& SW sprout & 6.71 & 8.62 & 7.88 & 8.24 & 4.23 & 8.59 & 44.27 \\
\hline
\end{tabular}

$\mathrm{ND}=$ not detected, $\mathrm{TW}=\mathrm{Tap}$ water, $\mathrm{SW}=$ Saline water.

Since, radish sprouts contain biogenic amines but it's lower than previous ranges, sprouts can be considered a safe food and germination of seeds either use tap or saline water did not cause harmful effect on the health of food. Besides, use sterilized seeds for sprouting caused big decrement in the amines content of radish sprout Table (5).

Over all, sterilization of seeds plays an important role to decrease the amines content which can be recommended treatment for decline the biogenic amines content of sprouts.

\section{REFERENCES}

Abdallah, M.M.F. 2008. Seed sprouts, A pharaoh's heritage to improve food quality. Arab Univ. J. of Agric. Sci., 16 (2), 469-478. 

evaluation of radish etiolated sprouts

AOAC. 2012 Official Methods of Analysis of AOAC International. $19^{\text {th }}$ Ed. Dumes Method. No. 968.06. Chapter 4, pp.25-26.

Cadenas, E. and Packer L. 2002. Handbook of antioxidants. Marcel Dekker, New York, USA, 712p.

Chavan, J.K. and Kadam S.S. 1989. Nutritional improvement of cereals by sprouting. Food Sci. Nutr. 28(5), 401-437.

Chima, C.E. and Jgyor M.A. 2007. Micronutrients and anti-nutritional contents of selected tropical vegetable grown in South East. Nigeria. Nig. Food. J. 25, 111-116.

Difco, 1989. Difco Manual of dehydrated culture media and reagents for microbiological and clinical laboratories products. $9^{\text {th }}$ Ed. Dfco laboratories, DetriotMi: Chgan, USA, pp. 937946.

Ding, H., Fu T. J. and Smith Michelle A. 2013. Microbial Contamination in Sprouts: How Effective Is Seed Disinfection Treatment?. J. of Food Sci., 78, 495-501.

Dung, D.D., Goodwin, I.R. and Nolan, J.V. 2010. Nutrient content and in sacco digestability of barly grain and sprouted barley. J. Anim. and Vet. Advan. 9, 2485-2494.

FDA, 1999. Food and Drug Administration Center for Food Safety and Applied Nutrition: Guidance for Industry, Sampling and Microbial Testing of Spent Irrigation Water During Sprout Production. Federal Register, 46(207), 5789357902.

Frias, J., Martinez-Villaluenga, G., Gulewiez, P., Perez-Romero, A., Plarski, R., Gulewiez, K., Vidal-Valverde, C. 2007. Biogenic amines and HL60 cytotoxicity of alfalfa and fenugreek sprouts. Food Chemistry 105, 959-967.

Georgela, D.L. and Boothroyd, M. 1965. A system for detection Salmonella in meat and meat products. J. Appl. Bacteriology, 28, 206.

Gouda, H. 2002. Microbiological studies on some fish aquacultures in Egypt, M.Sc. Thesis, Faculty of Agriculture, Cairo University, Egypt, pp. 52-69.

Ibrahim, E.M.R. 2010. Environmental and Nutritional Safe Production of Green Sprouts in House. M.Sc. Thesis, Department of Agriculture Science Institute of Environmental Studies and Research, Faculty of Agriculture, Ain Shams University, Cairo, Egypt. 87 p.

Khan, N.A. and McCaskey. 1973. Incidence of Salmonellae in commercially prepared sandwiches for the vending trades. J. Milk Food Technol. 39, 315-318.
Kim, H.U. and Goepfert J.M. 1971. Enumeration and identification of Bacillus cereus in Foods, 1.24- hour presumptive test medium. Appl. Microbial 22, 581-587.

Li, L., Dong Y., Ren H., Xue Y., Meng H. and Andminhui L. 2017. Increased Antioxidant Activity And Polyphenol metabolites in methyl jasmonate treated mung bean (Vignaradiata) sprouts. Food Sci. Technol, Campinas, 37(3), 411-417.

Lookhart, G. and Bean S. 1995. Separation and characterization of wheat protein fractions by high-performance capillary electrophoresis. Cereal Chem. 72 (6), 527-532.

Martinez-Villaluenga, C., Frias J., Gulewiez P., Gulewiez K. and Vidal-Valverde C. 2008. Food safety evaluation of broccoli and radish sprouts. Food and Chemical Toxicology. 46, 1635-1644.

NACMCF 1999.National Advisory committee on Microbiological Criterial for Food Microbiological safety evaluation and recommendation on sprouted seeds. International J. of Food Microbiology. 52, 123-153.

NMKL, Nordic Committee on Food Analysis 1995. Quality Assurance Guidelines for microbiological Laboratories. Report No. 86. $3^{\text {rd }}$ Ed., pp. 1044-1048,

Nout, M.J.R. 1994. Fermented foods and food safety. Food Res. Int., 27, 291-298.

Parente, E., Matuscelli M.., Gardini F., Grieco S., Crudele M.A. and Suzzi G. 2001. Evaluation of microbial populations and biogenic amines production in dry sausages produced in southern Italy. J. Appl. Microbiol., 90, 882-891.

Prokowich, K.D. and Blank G. 2001. Microbial evaluation of vegetable sprouts and seeds. J. Food Prot. 54, 560-562.

Rajkowski, K.T. and Thayer, D.W. 2001. Alfalfa seed germination and yield ration and alfalfa sprout microbial keeping quality following irradiation of seeds and sprouts. J. Food Port., 64, 1988-1995.

Shalaby, A.R. 1996. Significance of biogenic amines to food safety and human health. Food Research Inter., 29 (7), 675-690.

Shalaby, A.R. 2000. Changes in biogenic amines in mature and germinationg legume seeds and their behavior during cooking. Wiley- $\mathrm{VCH}$ Verlag GmbH, Weinheim. Nahrung 44 (1), 23- 27.

Sndecor, G.W. and Cochran, W.G. 1980. Statistical Methods. $7^{\text {th }}$ ed. Iowa State University Press. Ames, lowa, USA, 507p. 
Win,. T. and Oo, A.Z. 2017. Salt-stress-induced changes in protein profiles in two blackgram (Vigna Mungo L.) varieties differing salinity tolerance. Adv Plants Agric Res. 7(1), 206-210.
Zivkovie, S., Devic M., Filipovie B., Giba Z. and Grubisic D. 2007. Effect of $\mathrm{NaCl}$ on seed germination in some Centaurium Hill. Species (Gentianaceae). Arch. Biol. Sci., 59 (3), 227231. 
المؤتمر الرابع عشر لبحوث التنمية الزراعية، ماعدة

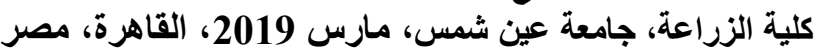

مجلد(27)، عدد (1)، عدد خاص مارس، مارس 2019 مارس $2013-605$

Website: http://strategy-plan.asu.edu.eg/AUJASCl/

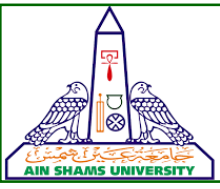

تاثير الماء المالح على النمو و التركيب الكيماوى والسلامه الميكروبية لتبت بذور الفجل

[57]

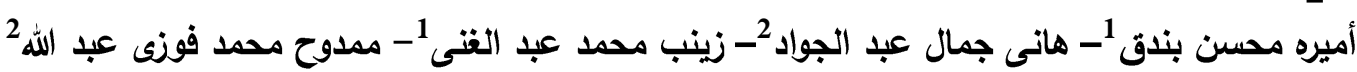

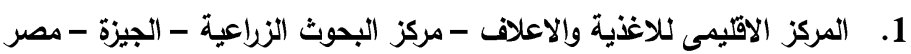

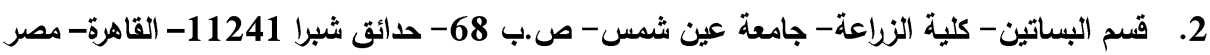

"Corresponding author: amirabondok@agr.asu.edu.eg

Received 24 February, 2019,

Accepted 31 March, 2019

بالنبت الناتج من ماء الصنبور • هذة الدراسة تم تقدير كل من العدد الكلى للبكتريا والعدد الكلى للكوليفورم

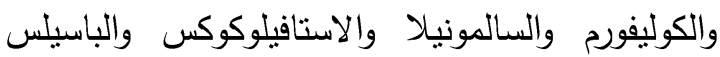

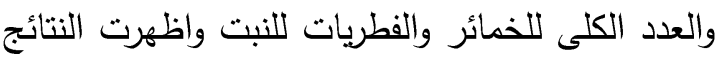
ان البذور المعقمة كانت خالية من جميع الميكروبات

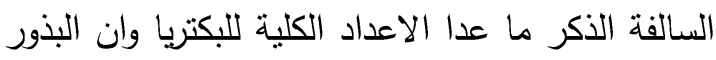
غير المعقمة كانت خالية من الميكروبات المرضية والاعداد الميكروبية الموجودة كانت في الحند الحدود الامنة. تم تقدير الأمينات الحيوية ووجد ان تتبيت بذور الفيل الفجل

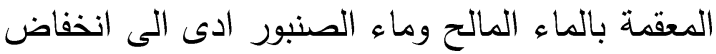

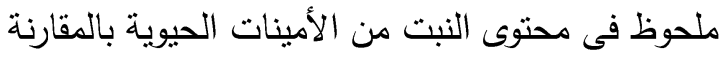

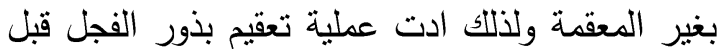

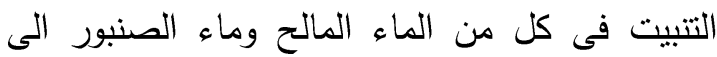

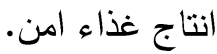

الكلمات الداله: نبت البذور، الفجل، التركيب الكيماوى، تفريدة البروتين، السلامة الميكروبية، البكتريا المرضية،

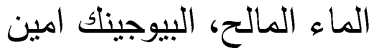

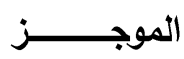

تم تقدير النمو و التركيب الكيماوى و تفريدة البروتين

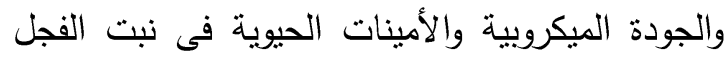

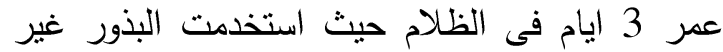

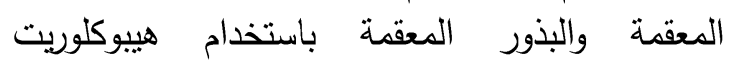
الكالسيوم 20 للتنبيت باستخدام ماء الصنبور و الماء

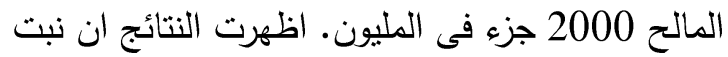
البذور المعقمة ادت الى تحسين صفات النبت الناتج بالمقارنة بنبت البذور غير المعقمة. كما تم تقدير التركيب الكيماوى للبذور النابتة بماء الصنبور و البندة الماء

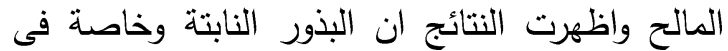

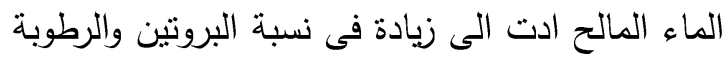
والالياف والرماد مع انخفاض فى نسبة الكروهيدرات

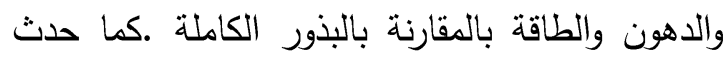
زيادة معنوية فى كل من الالبيومين، الجلوبيولين بلين

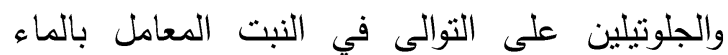
المالح، بينما حدث نقص معنى لتولى فين للبرولامين بالمقارنة 